\title{
Environmentally Conscious Consumption Patterns in Hungarian Households
}

\author{
Ágnes Hofmeister Tóth \\ Professor, Corvinus University of Budapest, Institute of Marketing and Media \\ E-mail: agnes.hofmeister@uni-corvinus.hu
}

\begin{abstract}
Kata Kelemen
Assistant researcher, Corvinus University of Budapest, Institute of Marketing and Media

E-mail:kelemenkata@yahoo.com
\end{abstract}

\author{
Marianna Piskóti \\ $\mathrm{PhD}$ student, Corvinus University of Budapest, Institute of Marketing and Media \\ E-mail: marianna.piskoti@uni-corvinus.hu
}

This article provides a comprehensive review of the literature on the theoretical aspects of sustainable consumption. The conditions for consumers' social responsibility and the formation of environmentally conscious behavior patterns will also be discussed, along with possible methods for motivating behavioral changes. The authors have completed a primary research study with the purpose of surveying environmentally conscious consumption patterns in Hungary. They also examined how the provision of appropriate information and the raising of awareness might encourage sustainable consumption. According to their findings, the respondents' knowledge on environmentally conscious behavior was rather limited, and reinforcement was needed in identifying appropriate activity alternatives. This paper provides a summary of the qualitative research phase which employed in-depth interviews, logging and focus groups. The consecutive application of these methods enabled the authors to keep track of the process and the consequences of raising awareness.

Keywords: sustainable consumption, consumer behavior patterns, Hungary

\section{JEL-codes:}

\section{Introduction}

A key element of the idea of sustainability is the rethinking of consumption. The revelation that society's current consumption habits may threaten the satisfaction of future generations' needs was formulated as already in the 1970s. Today's consumption patterns lead to the exhaustion of resources and to increased inter-country differences in quality of life. Achieving the goal of sustainable consumption depends in part on whether we can develop an understanding of the process of how the individual becomes committed and on whether we can identify any and all factors which can support or hinder this process.

\section{Tendencies in Environmentally conscious consumption}

There have been a number of studies dealing with citizens' environmentally friendly and harmful habits. One of those is a global research by National Geographic and GlobeScan (2008). Their findings indicate that consumers feel empowered as individuals and are willing to make changes in their consumption habits. Today, developing countries have a smaller ecological footprint and more sustainable consumption levels than their wealthy counterparts. The realization, however, that similarly to other nations their quality of life is also threatened by ecological problems is more characteristic for developing countries. They feel more 
responsible for environmental problems than developed countries. They are more likely to agree to take action and believe that it will make a difference. The study was repeated in 2009 and showed an increase in environmentally conscious consumer behavior. This trend, nevertheless, is supposed to be primarily a consequence of anti-crisis measures, with environmental aspects playing only a minor role (NationalGeographic - GlobeScan 2009).

European consumers are also becoming increasingly sensitive to ecological matters. According to a Eurobarometer survey, 96 percent of all Europeans consider environmental protection to be of their own personal interest. Two-thirds reported ecological problems to be very important to them (Eurobarometer 2008). Europeans are seriously worried about global environmental problems like climate change $(57 \%)$, water pollution $(42 \%)$ and air pollution (40\%). However, they expect to receive global answers to these concerns. Accordingly, they support the European Union's participation in environmental policy making.

The majority of Europeans have a positive attitude towards environmental protection and pay attention to their individual role as well. Respondents consider their quality of life to be influenced by the state of the environment $(80 \%)$ almost as much as by economic factors (84\%). Studies have also shown that although Europeans feel that environmental protection is necessary, this attitude is not always reflected in their behavior and specific actions. An impressive 59 percent of respondents said there was at least one thing during the current month they had done for the sake of the environment (usually waste recycling), however, only 3 percent were truly environmentally conscious. Europeans are not very willing to act in a way that directly affects their lifestyle and purchasing habits. They do not use their cars less frequently, nor do they buy green products. They do not realize that their consumption habits may potentially cause ecological problems.

Considering the tendencies outlined above, the introduction and the enhancement of appropriate consumption patterns is a key task, with social communication, education and nurturing all playing significant roles. The starting point is to develop a deep understanding of the characteristics of consumption and its underlying factors, topics that will be dealt with in detail below.

\section{Overview of the Literature}

Becoming a conscious consumer and adopting an adequate behavior is a long and complex process, in the course of which the individual gets acquainted with consumer goods and services and learns how to behave under market conditions. These are the processes as a result of which consumers become capable of enforcing their interests, of taking into account sustainability aspects, and of protecting natural resources (Ádám 2002).

To incorporate sustainability criteria into consumption habits, it is essential to identify the factors that most affect the consumers' relevant decisions. According to Zsóka (2007), the first step towards sustainable consumption is the individual's environmental consciousness, the presence and the depth of his/her ecological knowledge, ecological values, ecological attitudes, willingness to act and actual behavior.

The relationship between ecological knowledge and actual behavior has usually been found to be weak (Nagy 2005), because both ecological attitude and willingness to act may serve as weakening factors. The relationship is stronger, however, if knowledge on environmentally conscious behavior is considered instead of cognition of factual information on the environment. The relationship between ecological attitude and actual behavior (similarly to 
ecological values) is usually moderately strong, though results tend to vary from study to study. The strongest correlation is between willingness to act and actual behavior.

In addition to a positive attitude, actual behavior may also be influenced by several external factors. Consumers who lack the appropriate resources (infrastructural, financial etc.) will not be able to adopt the desired behavior. Also, an environmentally conscious consumption often means too much responsibility for the individual. This is due partly to the lack of well-defined criteria for ecologically appropriate consumption strategies, but safe products and services have also yet to specifically identified. Given these circumstances, consumers find it hard to decide which ecological criteria are relevant or which elements of ecological quality are the most important.

The complexity of the matter is also shown by the fact that there is more than one way to be environmentally conscious. The majority of consumers tend to choose only one or two factors instead of using the entire scope of opportunities. According to Meffert and Kirchgeorg (1994, cited by Nagy, 2005), environmentally conscious consumption can take the following five forms:

1. reducing the consumption of traditional products,

2. demand modification (purchasing environmentally friendly products instead of traditional ones),

3. consuming environmentally efficient products,

4. participation in waste recycling,

5. disapproval, protesting.

These behaviors (the first, second and fourth) affect people's routines. Their development, therefore takes some time, and people usually adopt them during their childhood. Changing traditional manners, consequently, requires the breaking of existing routines.

\subsection{Factors of the formation of environmentally conscious decision making}

Several comprehensive approaches to predicting consumer behavior and to handling the problem of individual will vs. environmental determination have already been developed. We are going to look at three that have contributed most to the theoretical background of our research.

A number of studies on environmental consciousness relied upon Ajzen and Fishbein's theory of reasoned action and on Ajzen's model of planned behavior. Although these two models focus on the formation of conscious behavior (and not on environmentally conscious behavior specifically), they have been widely employed in relevant studies.

In the theory of reasoned action (TORA), Ajzen and Fishbein (1980) emphasized that attitudes have no direct effect on behavior, they only influence one's behavioral intentions. Behavioral intention, however, is a function of several factors - e.g. attitudes, subjective norms and their relative importance. An improved version of the TORA model is the theory of planned behavior (TPB) (Ajzen 1985, 1991). New elements in this model are control beliefs and perceived behavioral control as a consequence of the former. Accordingly, persons with a strong internal control are convinced that they can achieve change through their behavior, while externally controlled individuals believe the exact opposite. In the model, Ajzen puts significant emphasis on perceived behavioral control, which influences behavior not only through behavioral intention but directly as well. It was the introduction of the element of actual behavioral control which made it a dynamic model (Ajzen 2002). See figure 1. 
Figure 1. The theory of planned behavior

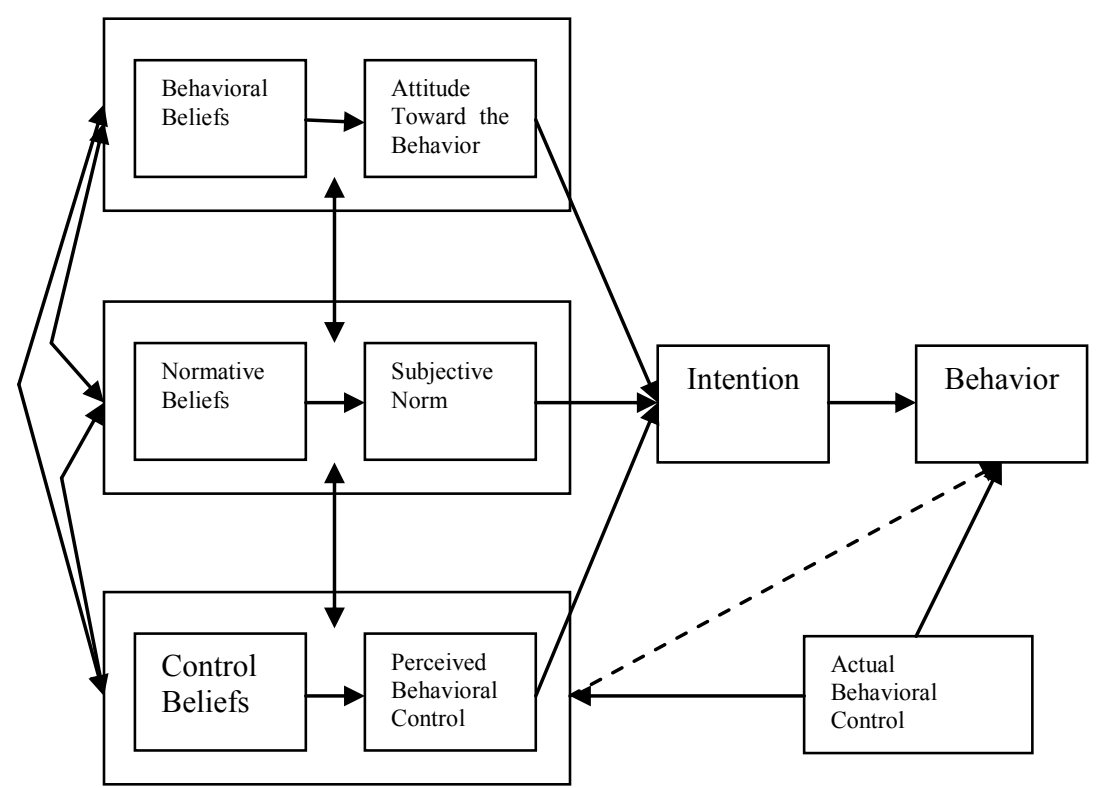

Actual behavioral control refers to the extent to which the individuals are able to achieve the desired outcome through their own behavior. The introduction of this latter factor is also significant when examining environmentally conscious behavior (Nagy 2005) as there are a number of non-controllable environmental factors related to environmentally friendly consumption. Consequently, economic and political legislation and directives are also necessary to make the realization of actual behavior easier for the individual. It is because of the non-controllable factors that even environmentally conscious consumers often act inappropriately in some situations.

The model employed by the OECD (Needs, Opportunities and Abilities model), approaching sectoral influencing factors from the aspect of needs, opportunities and abilities, allows for more practice-oriented applications and for a more comprehensive handling of noncontrollable factors (see figure 2).

An advantage of the model is that it deals both with micro and macro-level motivational factors. The main point is that consumers purchase goods and services in order to satisfy certain needs. Opportunities and abilities determine consumers' behavioral control. Opportunities represent external facilitating conditions, while abilities are internal factors enabling the purchase of any given product. Our findings will be presented in keeping with this structure. 
Figure 2. Needs, Opportunities and Abilities model

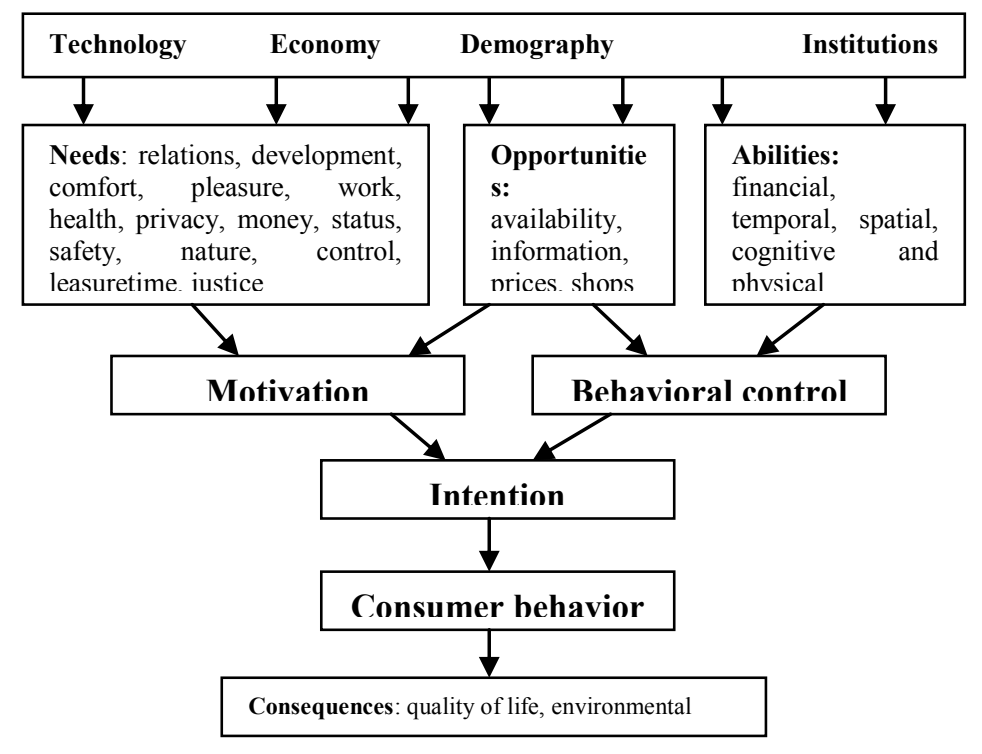

Sources: Gatersleben and Viek (1998), cited by OECD (2002)

\section{Qualitative Methodology}

Our research focused on the changes in environment-related consumer behavior patterns. We aimed at finding the factors with the most significant influence on consumers' proenvironmental behavior. We also intended to determine the degree to which individuals consider the protection of the environment to be their own responsibility and whether they feel hindered in their relevant efforts.

In order to develop a deeper understanding of the topic, we conducted a qualitative survey. The objective of this small-sample, non-representative survey was to identify the factors influencing changes and to develop the questionnaire of the quantitative survey based on our findings.

The qualitative survey was comprised of three stages, consecutively employing the techniques of in-depth interviews, logging and focus groups. The application of this combination of methods allowed for a multi-approach analysis and also enabled us to track ongoing changes. The in-depth interviews were used to outline the behavior patterns of participants and to determine how knowledgeable they are about the topic. The method was suitable for revealing underlying reasons and some deeper motivations. The next step was to raise consciousness on the environmental and ethical aspects of consumption. Subsequently, respondents were asked to log some aspects of their consumption behavior for an entire month. The period of one month was determined based on the budget period of a typical Hungarian family.

Finally, focus group meetings were organized with the purpose of sharing experiences, understanding obstacles and the joint discussion of personal impressions, feelings and opinions. At these meetings, we also looked into how the respondents' consumption behavior had changed, whether these changes could be maintained in the future, and surveyed the expansion of respondents' knowledge on the topic.

The survey was conducted in three regions, with a total of 20 respondents: Budapest (5 respondents), Miskolc (5 respondents) and Györ (10 respondents). Participants of the 
qualitative study had to be over 18 years of age with at least secondary school education and with a positive-to-neutral attitude towards the topic. A further requirement was that they not spend more than one week away from home during the research period.

We also appraised the living conditions of respondents. The majority lived in condominiums or tower blocks. The size of their homes was typically 40-49 sqm in Budapest, 35-200 sqm in Miskolc and 49-150 sqm in Györ. As regards consumer durables, all households had at least one TV set, DVD player or home theater system, a washing machine, a sound system, a refrigerator and a desktop computer, complemented with one laptop computer in every second household. Six households out of the twenty had a dishwasher, and one also had an air conditioner. There were no significant differences by region, except for the number of TV sets, which was higher in the countryside (2-3 pieces). This might be explained by the fact that the number of household members was larger in Györ and Miskolc than in Budapest. Countryside residents were also more apt to own a car than Budapest residents. While in Györ, there were 1 or 2 cars per household, only two of the Budapest respondents owned a car. The distance to the nearest selective waste collection container was $50-1000 \mathrm{~m}$ in Budapest, 10-1000 $\mathrm{m}$ in Miskolc and 50-5000 $\mathrm{m}$ in Györ.

The qualitative survey was conducted between May and November 2009. Respondents began logging their activities immediately after the in-depth interviews. Completed logs were analyzed by the project researchers. The focus group session outline was developed on the basis of the acquired information. The one month interval between the last log entry and the focus group session was intended to allow the assessment of the endurance of the changes which occurred during the logging period.

\section{Findings of the qualitative study}

We followed the line of thought of the NOA model both in establishing the theoretical background of our study and in classifying the factors to be analyzed. Our findings are also presented along the same structure. Micro- and macro-level factors, however, are presented according to how they were perceived by consumers (as opposed to the objective approach of the OECD).

\subsection{Micro-level factors}

\subsubsection{Identified needs}

We managed to identify five needs which affected consumers' decisions and thus the demand for environmentally conscious products and services. These were: comfort, trust, safety, health preservation and joy.

Comfort appeared as an important restrictive factor in the case of environmentally conscious activities requiring serious efforts from the individual. Respondents reported that abandoning existing purchasing routines and familiar products for new ones had been hard even when environmental advantages were obvious. They admitted not to switch over from familiar products either during the logging period, or afterwards. A typical answer would be: „No significant change in our family. Our children got used to those things, so we had to stick to them." (male respondent from Miskolc)

Comfort, again, was the primary reason for car use (easy shopping, transporting children, leisure trips and family visits) and for the selection of specific shopping locations as well. Concerning the latter, we must mention that respondents demonstrated a firm commitment to 
some (usually private label) bio or environmentally friendly products which encouraged them to visit more distant stores, as well.

Trust, too, was an important aspect. As environmentally friendly alternatives usually require some sort of financial or other sacrifice, the respondents' attitude depended largely on whether they perceived the environmentally friendly nature of the goods in question to be real. Several people reported to have been distrustful of products with bio or other environmental labels, and thus did not buy them. Those who had the opportunity opted rather for fruits and vegetables grown in their own or in their parents' backyard. Having reliable information about the type and the effects of any and all chemical treatments might be one explanation for this. A restrictive force in the case of labeled products was the disproportionately high price as compared to average food price levels.

Respondents often questioned the credibility of corporations' pro-environmental behavior as well. A concern related to selective waste collection was that even though households collect their waste selectively, it gets mixed up again during transportation. Price-related decisions also reflected the lack of trust. The majority of pro-environmental products are still more expensive. If consumers do not know why they pay that extra money or if they do not find it reasonable, saving some money remains a stronger motivating factor than environmental protection.

Safety concerns were brought up in the evaluation of the extent of packaging. Consumers' fear of infections prevailed over ecological aspects. The over-packaging of goods provides a feeling of reassurance to consumers who are concerned about food safety. The use of various aggressive detergents was also explained by respondents' belief that this is the only way they can be sure about the hygiene of their living environment. The need for health preservation, however, was accompanied by the prevalence of ecological aspects.

One further need was the desire for joy which often leads to over-consumption. Here, shopping served as a vehicle of self-reward. A female respondent from Budapest said: „I think this might be a way of life or a kind of reward strategy in people's life. When they are in a bad mood they go to a shopping mall to try to find something that makes them happy and even though they may already have six pieces of whatever they buy, their attitude is: why shouldn't I have a seventh one?"

\subsubsection{The scope of opportunities}

From amongst all the opportunities, participants emphasized prices, infrastructural conditions and the availability of information.

According to their responses, price is one of the most decisive factors in purchase decisions. Price consciousness was also fueled by the economic crisis. Respondents often argued that pro-environmental products are unaffordable or that they provide lower quality for a similar price.

Infrastructural difficulties were mentioned primarily in the case of selective waste collection. There are too few collection points and the containers also proved to be too small for the needs of the communities. Moreover, collection points are sometimes located too far away from people's homes, which is why consumers, reluctant to give up their comfort, do not commit themselves to selective waste collection. This was characteristic for Miskolc and Budapest, where selective waste collection was not found to be typical. They perceived the distance of collection points to be a severe obstacle and believed home pickup to be more 
reasonable. In contrast, in Györ, where selective waste collection had been introduced earlier than in any of the two other regions, attention had already shifted to the proper management of waste materials.

An important factor already revealed during the in-depth interviews was that participants were not properly informed. Even though they were fed up with communication campaigns, there was still a lack of information on appropriate environmentally conscious consumption strategies.

The limited availability of information was perceived by respondents as a fundamental barrier. They believe that each and every initiative aimed at handling these problems on the community level and at providing information for them is important. At the same time, participants could hardly mention any specific civil organizations they could direct their questions to on environmentally conscious consumption. As a result of the study, they came to know environmental protection organizations and one respondent from Györ even became a supporter of Greenpeace.

\subsubsection{The role of abilities}

Respondents' abilities were most prominently determined by their income and their knowledge. Some of them reasoned that their income does not allow for ecological aspects to be taken into consideration. Another problem was the financing of solutions with slow returns. These were mentioned primarily in the case of consumer durables. In the case of lowvalue items, like light bulbs, the need for economization made the switch to environmentally friendly goods somewhat easier. The same is true for energy and water consumption, where environmentally friendly modes of use were mentioned only if specifically asked for but not spontaneously.

Existing knowledge and previous experiences largely determined the extent to which participants were knowledgeable about environmentally conscious alternatives and the extent to which they used them. The lack of knowledge and the feeling of having too little information were characteristic for all three regions. This was often accompanied by mistrust and by the underrating of ecological aspects simultaneously. It was only during the logging period that some respondents realized that certain of their activities and decisions are actually correct from an environmental point of view. Participants also frequently felt that environmentally conscious consumption was a much too complex, complicated task. Furthermore, we observed that those who had some information of the topic due to previous experience, were much more conscious in their decision making and in sharing their knowledge during the course of the study.

Due to the strong restrictive factors among opportunities and abilities, the perceived behavioral control of respondents remained very low even though they did feel the importance of the individual's responsibility. Respondents developed the feeling that their scope of possible actions had been far too much determined by external, macro-level factors.

\subsection{Macro-level factors}

\subsubsection{Institutional conditions}

Generally, respondents expected more extensive state participation in a number of different areas. The formulation of environmental strategies, the development of relevant legislation, control measures and the facilitation of financing efforts were mentioned as primary tasks of the government. A male respondent from Budapest said: „So, we might develop an 
environmentally conscious way of thinking, but we cannot put it into practice, as the packaging is just as it is, the collection point is just where it is, this ethics code in the case of Hungarian products fails, etc. I think that the whole process should basically be set into motion by some kind of top-to-bottom pressure or strategy."

Fiscal incentives were most frequently mentioned as a possible way to stimulate change. The support of positive behavior and the sanctioning of inappropriate behavior were both considered to be acceptable. „Environmentally friendly products could be subsidized, for example," according to a female participant from Miskolc.

Several respondents emphasized the importance of clear guidance and the comprehensibility and availability of information. Some further suggestions included the development of an appropriate infrastructure, reforms in public transportation, the revision of waste collection and management processes, the support of alternative energy sources, the promotion of Hungarian companies' competitiveness (thereby reducing the price of Hungarian products) and the support of environmentally friendly innovations. State responsibility was even overemphasized in some cases: "If the government imports products into Hungary that were not manufactured using environmentally friendly processes, they cannot expect people not to buy them" (female participant from Budapest).

From their later statements, it turned out that these obstacles can actually be overcome, yet they are very suitable for denying individual responsibility.

In the case of corporations, respondents emphasized the need for these companies to take real responsibility. Rapidly developing technologies should actually enable the companies to reduce emissions. Pro-environment products should be supported during product development, and the life cycle of products should be lengthened instead of being continuously shortened. Corporations are also considered to be responsible for supporting consumers' environmentally friendly behavior.

\subsubsection{Economic conditions}

Consumers often reacted to recent years' remarkable expansion in product choice and promotions with over-consumption. Respondents ascribed this kind of behavior to advertisements, quantity discounts and limited offers. According to a female participant from Budapest, ,if you see that right now you can get three for the price of two, and you like the product, then you just buy it. Yes, it might very well spoil, but you still buy it."

The restrictive effects of the economic crisis acted against over-consumption. This was most apparent in Györ. Even though none of the respondents reported a decrease in their income as a result of the crisis, they still argued that it is because of the crisis that they cannot afford to buy the more expensive environmentally friendly product alternatives. The crisis also motivates people to pay more attention to what they spend their money on. Economization is, of course, an efficient motivation for environmental protection. Respondents reported having paid special attention to their energy and water consumption during the logging period. They switched to energy saving light bulbs, switched off unnecessary electronics devices, and always turned off the lights. Consciousness was also introduced into their grocery purchases they strove to buy only what they really needed. 


\subsubsection{Technological conditions}

Respondents also used technological obsolescence as an explanation for over-consumption. In a number of products, innovation is so fast that consumers are forced to make new purchases again and again if they want to keep up with the pace. Specifically, the compatibility problems of some electronic devices and the binding of some services to specific equipment were mentioned by respondents. „There are ways in which they can force us. I see this mainly in the electronics market, e.g.: mobile phones, and in markets where newer and newer products are launched each day. They keep on developing, keep on innovating to make us replace what we have", argued a female participant from Györ.

From another aspect, technological development may also make it easier to act in an environmentally conscious way. Respondents from Györ were generally worried about the proper management of selectively collected waste. The less advanced waste recycling technologies employed in Hungary make consumers feel that their efforts in selective waste collection are unnecessary.

\subsubsection{Cultural characteristics}

Ecological education, which appeared in several stages of the qualitative study, was classified as a macro-level factor. Respondents clearly expressed the need to have an environmentally conscious way of thinking and behavior become an everyday norm and routine for future generations. This is a common task for the state, media, families and communities, all of which can initiate and support environmentally conscious education.

Media is responsible for improving people's awareness. Although consumers are fed up with communication campaigns, there still is a lack of information on appropriate environmentally conscious consumption strategies. According to a female participant from Györ, „the problem is that a couple of us know about this, but it is not advertised that one should have a look at it. These things should be communicated better! It could be on television, on the radio or on flyers that "hey people, pay some attention to how you could possibly live more consciously!"

It was sad that participants could not mention a single personality from Hungary with whom they could possibly associate environmentally conscious behavior, the idea of sustainable consumption. They did not know of famous people who had already committed themselves to this, neither did they know anyone who could potentially support these ideas (because consumers would trust their word).

After some further questions, they gathered some criteria such celebrities would have to fulfill. Respondents from Miskolc definitely voted for sportspersons because of their focus on good health, as that kind of awareness might have a positive effect on their environmental behavior. Another important aspect (also brought up in Györ) was that it should be a person with strong morals, who goes his/her own way, for whom money does not constitute a motivating factor to participate in the campaign.

Interestingly enough, participants' thoughts focused primarily on female candidates. When instructed to do so, they named male celebrities whom they knew to have already stood up for some community's interest concerning some other social issue. These aspects and the ultimate problem of choosing a credible person must be taken into account when developing relevant communication strategies.

\section{Changes resulting from the research method applied and their endurance}


In some cases, keeping a log allowed for the development of enduring changes. Already existing environmentally conscious activities were maintained, and the degree of consciousness even improved sometimes. These routines were only abandoned if the respondent was removed from his/her own environment (visiting friends or relatives, holidays, weekend trips etc.). Changes were of a rather ad-hoc nature, often as a kind of compensation when their routine activities were hindered by some factor.

The most enduring change was related to the use of own shopping bags. As this is an easily adoptable activity, even respondents who had not paid attention to the topic when they had begun logging demonstrated some improvement. There was a certain degree of improvement concerning selective waste collection, as well. This affected primarily respondents from Budapest and Miskolc, as Györ residents had acted consciously right from the beginning.

Only smaller, easily achievable changes took place in the respondents' behavior. None of the respondents demonstrated a change of a more comprehensive nature. During the thirty-day period in question, no significant turning points or stages could be identified. At the same time, due to the complexity of the problem, no such findings were expected. Nevertheless, during the research process, respondents became motivated for activities requiring smaller efforts. Strong emotional attachment was avoided as they considered logging simply to be a task to be completed. This way, they managed to avoid cognitive dissonance, which might have improved their motivation for achieving more difficult changes.

\section{Conclusions}

The set of qualitative techniques employed in the study enabled participants to feel closer to the research problem and thus to formulate supporting and hindering factors more specifically.

In the early stage of the study, respondents' preliminary knowledge was typically very limited. The majority had a false understanding of the notion of sustainable consumption and they only associated its economic aspects with it. They were also uncertain when asked about the specifics of some ecological problems. The sole exception was respondents who had acquired more thorough ecological knowledge through previous experiences or education. Female participants usually began developing a stronger emotional attachment as early as during the in-depth interviews, their attention, however, was always focused only on a single topic. Males, on the contrary, employed a more comprehensive approach and often admitted to not being environmentally conscious. The differences we found need to be confirmed by further research.

The logging activity following the in-depth interviews was intended to turn sustainable activities into a routine, to make participants conscious of these activities through practice and to develop a feeling of involvement. Findings showed that respondents primarily kept up their already existing positive practices. Any other changes in behavior were of an ad-hoc nature and proved to be merely temporary.

Focus group sessions, however, revealed that the one-month log keeping period often resulted in participants becoming conscious about their existing positive practices. This acted as a kind of reinforcement and thus motivated them to practice such activities more intensively. The changes observed, however, constituted only a couple of small and easy steps, like always turning off the lights or not wasting water when having a shower or doing the dishes. Respondents, thus, perceived these processes as changes, even though it was not reliably 
reflected in their actions. After all, what we observed was a shift in their attitudes, as they developed a more positive attitude towards sustainable consumption patterns, yet their knowledge has not yet been fully transformed into practice.

We managed to identify a number of influencing factors. Respondents put the strongest emphasis on ensuring a supportive environment, which, according to them, should include some additional regulations and make existing regulations easier to comply with. As regards the latter, they mentioned that beyond the appropriate infrastructural support, they also need some practical knowledge about the topic in order to comply with the rules. Accordingly, easy availability and usability of pro-environment solutions, comprehensible relevant information and frequent feedbacks might significantly speed up the adoption of good practices. The respondents suggested the following ways to help to motivate appropriate behavior. In cases where environmentally friendly practices did have their roots in the past and thus consumers could reasonably be expected to have the necessary experience, they opted for sanctions - e.g. littering. For relatively new forms of behavior, like selective waste collection, they focused more on guidance, the availability of practical information and on the solution being comfortably accessible. Another form of support was financial motivation, such as the sale of environmentally friendly solutions at lower prices and employing state incentives in promoting their availability or use.

Respondents considered the state to be the most important driving force in promoting environmentally conscious consumption. Changes in their behavior were described as part of a state-coordinated process. Bottom-up environmental initiatives were hardly mentioned.

Table 1. Effects of the factors on environmentally conscious consumer behavior

\begin{tabular}{|c|c|c|c|}
\hline \multicolumn{3}{|c|}{ Factors } & Effect \\
\hline \multirow{12}{*}{ 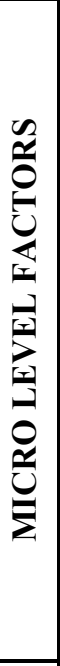 } & Needs & Comfort & - \\
\hline & & Trust & - \\
\hline & & Safety & - \\
\hline & & Health preservation & - \\
\hline & & Desire for joy & - \\
\hline & Opportunities & Infrastructural difficulties & - \\
\hline & & Lack of information & - \\
\hline & & Community level & + \\
\hline & & Civil organizations & + \\
\hline & Abilities & Income & - \\
\hline & & Lack of knowledge & - \\
\hline & & Behavioral control & - \\
\hline \multirow{9}{*}{ 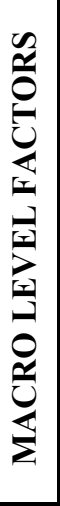 } & Institutional conditions & State participation & + \\
\hline & & Fiscal incentives & + \\
\hline & & Lack of clear guidance & - \\
\hline & Economic conditions & Product choice & - \\
\hline & & Promotions & - \\
\hline & & Crisis & + \\
\hline & Technological conditions & Technological obsolescence & - \\
\hline & & Technological development & + \\
\hline & Cultural characteristics & Ecological education & + \\
\hline
\end{tabular}

(+) already existing positive effect, $(+)$ potential positive effect, (-) already existing negative effect 
Participants usually did not consider this process to be one that they could or wanted to control individually. Often, the reasons were the lack of trust and the denial of responsibility, partly as a result of the former. Behavioral changes initiated by the individual, if present at all, originated in financial or health considerations rather than in environmental consciousness.

This was also confirmed in the part when we asked respondents about personalities who might be associated with environmental consciousness. Participants could not name anyone who they thought could credibly represent the idea of sustainable development, and when asked for the second time, they only mentioned sportspersons and other personalities known for their commitment to a healthy lifestyle. This also confirms our assumption that health consciousness might provide a basis for developing an environmentally conscious behavior.

The achievement participants considered to be the most significant was that the idea of environmental consciousness, requiring rather complex activities, could be simplified and broken down into tasks they already knew. As a result participants, especially females, became more involved and more confident. Providing easy-to-comprehend solutions to environmentally conscious consumption might be an efficient form of communication capable of inducing real changes. The difficulty here is that different regions might have different problems and it may be difficult to address them in a single message. Continuous feedback and reinforcement to the individual might also be very useful in fostering change. Large-scale changes take much longer to occur and they also necessitate a well-founded, supportive atmosphere suitable for providing answers to uncertain consumers even in the simplest possible topics (How shall I dispose of it? Why shall I do it this way? What happens to the waste in selective containers? etc.). As regards reinforcement, we have to emphasize how important it is for the people to know why they are doing something and to receive positive feedback regularly.

\section{References}

Ajzen, I. (1985): From intentions to actions: A theory of planned behavior. In: Kohl, J. Beckman, J. (Eds.): Action control: From cognition to behavior. Heidelberg: Springer.

Ajzen, I. (1991): The theory of planned behavior, Organisational Behavior and Human Decision Processes 50: 179-211.

Ajzen, I. (2002): Perceived Behavioral Control, Self-Efficacy, Locus of Control, and the Theory of Planned Behavior. Journal of Applied Social Psychology 32: 665-683.

Ajzen, I. - Fishbein, M. (1980): Understanding Attitudes and Predicting Social Behavior. Englewood Cliffs, NJ: Prentice Hall.

Ádám Ferencné (2001): Fenntartható fogyasztás családi és iskolai közösségekben [Sustainable Consumption in Family and School Communities]. In: Nyitrainé - Varga (Eds.): Bimbó boci bóklászása és más ötletek a fenntarthatóságra neveléshez. [The stumbling of "Bimbó calf" and other ideas for the training of sustainability]. Budapest: Magyar Környezeti Nevelési Egyesület.

Gatersleben, B. - Vlek, C.A.J. (1998): Household consumption, quality-of-life and environmental impacts: a psychological perspective and empirical study. In: Noorman, K.J. and Schoot Uiterkamp, T. (Eds.): Green households? Domestic consumers, environment and sustainability. London: Earthscan, 141-183.

Hofmeister Tóth, Á. (2008): Generációs különbségek a fogyasztáshoz való viszonyban. [Generational Differences in the Relation to Consumption] In: Temesi, J. - Berács, J. (eds.): 60 éves a KÖZGÁZ Jubileumi kötet. Budapest: Aula Kiadó. 
Meffert, H. - Kirchgeorg, M. (1994): Grundlagen des Umweltschutzes aus wettbewerbsstrategischer Perspektive [Principles of Environmental protection from a competition strategy perspective), in: Hausmann, K.W. (Eds.): Schriften zur Unternehmensführung ,,Marktorientiertes Umweltmanagement. Band 50/51. Wiesbaden: Verlag Gabler

Nagy, Sz. (2005): Környezettudatos Marketing [Environmentally Conscious Marketing]. Miskolc: Miskolci Egyetem Gazdaságtudományi Kar

NationalGeographic - GlobeScan (2008): Greendex 2008: Consumer Choice and the Environment - A Worldwide Tacking Survey. http://www.nationalgeographic.com/greendex/assets/GSNGS Full_Report May08.pdf

NationalGeographic - GlobeScan (2009): Greendex 2009: Consumer Choice and the Environment - A Worldwide Tracking Survey. http://www.nationalgeographic.com/greendex/assets/GSNGS_Full_Report_May09.pdf

Nemcsicsné Zsóka, Á. (2007): A fenntartható fogyasztás alapfeltétele: a környezettudatos egyéni magatartás [The Basic Condition of Sustainable Consumption: The Environmentally Concious Behaviour of the Individual]. In: Gulyás, E. - Vadovics, E. (Eds.): Fenntartható fogyasztás Magyarországon 2007. Konferenciakötet http://www.tve.hu/attachment/file/31/Fenntarthato fogyasztas konferenciakotet.pdf

Noorman, K. - Uiterkamp T. S. (1998): Green households? Domestic Consumers, Environment and Sustainability. UK.: Earthscan Publications Ltd.

OECD (2002): Towards Sustainable Household Consumption? Trends and Policies in OECD Countries. Paris: OECD

Eurobarometer (2008): Attitudes of European Citizens towards the Environment. Special Eurobarometer, http://ec.europa.eu/public_opinion/archives/ebs/ebs_295_en.pdf 